Amanda Aparecida Silva'

José Maria Pacheco de Souza"

Flávio Notarnicola da Silva

Borges $^{1}$

Frida Marina Fischer"II

\section{Health-related quality of life and working conditions among nursing providers}

\section{Qualidade de vida associada a saúde e condições de trabalho entre profissionais de enfermagem}

Programa de Pós-Graduação em Saúde Pública, Faculdade de Saúde Pública (FSP). Universidade de São Paulo (USP). São Paulo, SP, Brasil

Departamento de Epidemiologia. FSP-USP. São Paulo, SP, Brasil

III Departamento de Saúde Ambiental. FSPUSP. São Paulo, SP, Brasil

Correspondência | Correspondence: Amanda Aparecida Silva Av. Doutor Arnaldo, 715 - Cerqueira César 01246-904 São Paulo, SP, Brasil

E-mail: amandaas@usp.br

\begin{abstract}
OBJECTIVE: To evaluate working conditions associated with health-related quality of life (HRQL) among nursing providers.

METHODS: Cross-sectional study conducted in a university hospital in the city of São Paulo, Southeastern Brazil, during 2004-2005. The study sample comprised 696 registered nurses, nurse technicians and nurse assistants, predominantly females $(87.8 \%)$, who worked day and/or night shifts. Data on sociodemographic information, working and living conditions, lifestyles, and health symptoms were collected using self-administered questionnaires. The following questionnaires were also used: Job Stress Scale, Effort-Reward Imbalance (ERI) and Medical Outcomes Study 36-Item Short-Form Health Survey (SF-36). Ordinal logistic regression analysis using proportional odds model was performed to evaluate each dimension of the SF-36.
\end{abstract}

RESULTS: Around $22 \%$ of the sample was found to be have high strain and $8 \%$ showed an effort-reward imbalance at work. The dimensions with the lowest mean scores in the SF-36 were vitality, bodily pain and mental health. High-strain job, effort-reward imbalance (ERI $>1.01$ ), and being a registered nurse were independently associated with low scores on the role emotional dimension. Those dimensions associated to mental health were the ones most affected by psychosocial factors at work.

CONCLUSIONS: Effort-reward imbalance was more associated with health than high-strain (high demand and low control). The study results suggest that the joint analysis of psychosocial factors at work such as effort-reward imbalance and demand-control can provide more insight to the discussion of professional roles, working conditions and HRQL of nursing providers.

DESCRIPTORS: Nursing Staff. Working Conditions. Quality of Life. Health Status. Cross-Sectional Studies. Psychosocial factors at work. 


\section{RESUMO}

OBJETIVO: Avaliar condições de trabalho associadas à qualidade de vida relacionada à saúde entre profissionais de enfermagem.

MÉTODOS: Estudo transversal realizado em um hospital universitário de São Paulo, SP, em 2004-2005. A população estudada foi de 696 enfermeiros, técnicos e auxiliares de enfermagem, predominantemente feminina $(87,8 \%)$ e que trabalhava em turnos diurnos e/ou noturnos. Os dados sociodemográficos, de condições de trabalho e de vida, hábitos de vida e sintomas de saúde auto-referidos foram obtidos por meio de questionários auto-aplicados: Resultados de Estudos de Saúde - versão reduzida, Escala de Estresse no Trabalho e Desequilíbrio Esforço-Recompensa. Valores do coeficiente $\geq 1,01$ significam mais esforços do que recompensas no trabalho. Modelos de regressão logística ordinal de chances proporcionais foram ajustados para cada dimensão do SF-36.

RESULTADOS: Aproximadamente $22 \%$ da população foi classificada como trabalhando em condições de alto desgaste e $8 \%$ com mais esforços do que recompensas no trabalho. As dimensões com piores escores médios no SF-36 foram vitalidade, dor e saúde mental. Alto desgaste no trabalho, ter mais esforços que recompensas e ser enfermeira associaram-se de maneira independente aos baixos escores da dimensão de aspectos emocionais. As dimensões relacionadas à saúde mental foram as que mais sofreram influência dos fatores psicossociais do trabalho.

CONCLUSÕES: Apresentar mais esforços do que recompensas no trabalho foi mais significativo para a qualidade de vida associada à saúde do que o alto desgaste no trabalho (altas demandas e baixo controle). Os resultados indicam que a análise conjunta dos fatores psicossociais de desequilíbrio esforçorecompensa e demanda-controle contribuiu para a discussão sobre os papéis profissionais, condições de trabalho e qualidade de vida relacionada à saúde de profissionais de enfermagem.

DESCRITORES: Recursos Humanos de Enfermagem. Condições de Trabalho. Qualidade de Vida. Nível de Saúde. Estudos Transversais. Fatores psicossociais no trabalho.

\section{INTRODUCTION}

Psychosocial and work organization factors have been special objects of interest of study and interventions in the light of the precarious and unstable relationship between work and production, ${ }^{19}$ the nature of illnesses among workers, and a growing concern with people's well-being and quality of life.

Psychosocial factors at work are associated to the interaction between environment and working conditions, job duties and individual worker characteristics taking into account all their features and demands, including those outside the work environment. Workers' health and work performance are affected by these interactions and their experience. ${ }^{11}$

Studies with populations of workers have suggested that psychosocial stressors such as high psychological strain, lack of control and social support, high effort and reward at work and overcommitment can be associated to low quality of life and disease development. Some studies have investigated the relationship of these stressors with health condition, ${ }^{12,15}$ mental health, ${ }^{4}$ coronary disease,,$^{12,17}$ and symptoms, signs or disability arising from musculoskeletal problems. ${ }^{9,10,22}$

In recent years special attention has been paid to nurses' health. These providers are usually subject to different physical loads determined by psychosocial stressors such as close attention, lack of understanding of the tasks, fast task performance, repetitive and fragmented tasks, low social support, lack of recognition and reward, high emotional demands, night work and lack of job security. ${ }^{16}$ As they work 12 -hour night shifts these workers tend to have more than one productive activity, which results in work overload and long working days. ${ }^{8}$ Because of this workload some providers end up withdrawing from work due to health problems ${ }^{19}$ and giving up this occupation prematurely. ${ }^{7}$ Despite 
there are many studies on nursing, they do not assess the relationship between nurses' perceptions of their working conditions and health-related quality of life (HRQL). ${ }^{3,4,14,16} \mathrm{HRQL}$ is a concept and/or a form of assessment of health condition that has gained relevance in patient populations in recent decades. It has also been increasingly recognized as an important health outcome among healthy populations including workers. There is no widely accepted definition for HRQL, primarily because it is used in different contexts. HRQL is here defined as the impact of a health condition on aspects that affect quality of life. ${ }^{20}$

The present study aimed to evaluate working conditions associated with HRQL among nursing providers. We tried to verify the following hypotheses: (i) that differences in these perceptions are associated to different nursing categories; (ii) that the combined assessment of psychosocial stressors, in terms of demand and control and effort and reward at work, can provide better explanations on the association between nurses' perception about working conditions and HRQL.

\section{METHODS}

This study was based on secondary data from a crosssectional study conducted at a university hospital in the city of São Paulo, Southeastern Brazil, in 2004-2005 published elsewhere. $^{8}$

Nursing providers (registered nurses, nurse technicians and nurse assistants) who have been working at least three months in the hospital were invited to participate in the study. There were excluded those on medical leave $(\mathrm{n}=21)$ and maternity leave $(\mathrm{n}=5)$. From a total of 996 eligible providers, $696(69.9 \%)$ agreed to participate in the study. There were no statistical differences of gender, age, and time working at the hospital between those who agreed and those who refused to participate in the study, which suggests homogeneity between these groups. Most participants were female (87.8\%), younger than 40 years old $(67.4 \%)$, single/ widowed or divorced (56.0\%), single head of household $(54.9 \%)$, and with no college education $(54.6 \%)$. Of all, $16.8 \%$ reported smoking, $39.7 \%$ alcohol use and $50.4 \%$ reported engaging in physical exercise. Nurse technicians or assistants comprised $77.6 \%$ of the sample studied. At this hospital, $47 \%$ worked a 12-h night shift (7:00 pm to 7:00 am) followed by 36-h off-time; $17.7 \%$ worked 9-h day shifts (7:00 am to $4 \mathrm{pm}$ ), and 35.3\% worked 6-h day shifts (morning shift: 7 am to $1 \mathrm{pm}$ or afternoon shift: $1 \mathrm{pm}$ to $7 \mathrm{pm}$ ). The number of jobs and work shifts were as follows: 1 or 2 day jobs $-49.6 \%$; 1 or 2 night jobs $-35.2 \%$; and 1 day and 1 night job $15.2 \% .{ }^{8}$ Overcommitment at work was found in $58.5 \%$, and low social support in $59.8 \%$.
Data were collected using a combination of self-administered questionnaires. The current study included sociodemographic information (gender, age, head of household, and marital status), working conditions (number of jobs and work shifts, weekly working hours and nursing category, social support at work, overcommitment, work-related injuries), habits and lifestyle (cigarette smoking, alcohol use and physical exercise), and versions of the following questionnaires were translated and adapted into Brazilian Portuguese: Job Stress Scale (short version of Job Control Questionnaire); ${ }^{2}$ Effort-Reward Imbalance ${ }^{5}$ (ERI) scale; and the Medical Outcomes Study 36-Item Short-Form Health Survey (SF-36). ${ }^{6}$

The demand-control scale comprises four categories combining psychological demands and control at work based on the intersection between high and low demands and high and low control as follows: lowstrain job (high control, low demand), active job (high demand, high control), passive job (low demand, low control), and high-strain job (high demand and low control). The latter represents the highest risk. ${ }^{2}$

ERI ratio describes the relationship between effort and reward at work through the association between the related scores. Coefficients higher than one indicate high effort with low reward, classified as inadequate. ${ }^{5}$

The SF-36 is a generic questionnaire on HRQL from a multi-dimensional construct. It consists of 36 items or questions which represent eight health dimensions. The dimensions exclusively related to physical health are: physical functioning (ten items), role physical (four items) and bodily pain (two items); those exclusively related to mental health are: social functioning (two items), role emotional (three items) and mental health (five items). General health (five items) and vitality (four items) can belong to both physical and mental dimensions. ${ }^{24}$ There is a further unscaled single item asking respondents about health changes over the past year. Each dimension is a $0-100$ scale, with the highest score representing the best outcome. The definitions of dimensions and methods of score calculation can be found in Ware \& Sherbourne ${ }^{24}(1992)$ and Ciconelli (1997). ${ }^{a}$ For data analysis, each scale was categorized into tertiles and the highest scores were in the first tertile and the lowest scores in the third tertile.

Nurse technicians and assistants were grouped into the same professional category and registered nurses were included in a distinct group.

Pearson's $\chi^{2}$ test was used to test the association between the two groups of professional categories and their perceptions about working conditions (low-strain,

a Ciconelli RM. Translation into Brazilian Portuguese and validation of the quality of life assessment questionnaire "Medical Outcomes Study 36- Item Short-Form Health Survey (SF- 36)" [doctorate thesis]. São Paulo: Universidade Federal de São Paulo; 1997. 
active, passive, and high-strain job). Similarly, the Pearson $\chi^{2}$ was used to test the association between professional categories and effort-reward ratio.

In order to assess the association between HRQL scores and perceptions about working conditions, the SF-36 eight dimensions were considered as dependent variables. Given the ordinal nature of the scales, a proportional odds model was built for logistical ordinal regression analysis. This model compares the probability of a response equal to or lower than a given category with the probability of a response greater than that category using odds ratio (OR). ${ }^{1,13}$ For each SF-36 dimension comparisons between tertiles were made as follows: $\mathrm{OR}_{1}=$ first tertile versus second + third tertiles and $\mathrm{OR}_{2}=$ first + second tertiles versus third tertile. The ordinal regression analysis procedure is detailed in the appendix of the manuscript published online.

Bivariate models were constructed for demand-control, ERI ratio and job title (professional category), followed by a multiple model for each of the eight SF-36 dimensions. Each multiple model was adjusted by adding variables in the following order: demand-control, ERI ratio, and job title. Other variables such as sociodemographic, lifestyle and other work variables were included in the final eight models as control variables.

Significant parameters were those which confidence intervals (CI) did not include the value 1 (logistic regression model) or $\mathrm{p}<0.05$ (Pearson $\chi^{2}$ ). All analyses were performed using Stata v. 9.1 with logit function, and SPSS (v. 12.0).

The participation of nursing providers was voluntary. The study was approved by the Research Ethics Committees of Universidade de São Paulo School of Public Health and the study hospital according to Ethical Principles for Research Involving Human Subjects, Resolution 196/96 of the Brazilian Ministry of Health.

\section{RESULTS}

The following was found for the variable demandcontrol in the study sample: $23.1 \%$ had low-strain jobs, $25.0 \%$ active jobs, $29.7 \%$ passive jobs, and $22.1 \%$ high-strain jobs. Regarding ERI ratio, 92.2\% reported an adequate effort-reward ratio $(\mathrm{ERI} \leq 1)$.

As for SF-36, although vitality and pain showed low scores, dimensions exclusively related to mental health generally had lower means compared to those exclusively related to physical health (Table 1).

Tables 2 and 3 show comparisons between perceptions about working conditions among professional categories. They refer to the hypothesis that different professional categories evaluated their working conditions differently. The results indicate that registered nurses perceived greater control at work (active and low-strain jobs) compared to nurse technicians and assistants but they showed higher effort-reward ratio. Notwithstanding, the proportion of nurse technicians and assistants who perceived inadequate effort-reward was approximately half of that of registered nurses in the same category, indicating that a greater proportion of registered nurses perceived their working conditions as worse than those of nurse technicians/assistants.

Table 4 presents the results of the logistical ordinal regression analysis using the proportional odds model. Only the role emotional dimension had significant scores for the three variables demand-control, ERI ratio and job title. Providers whose working conditions were classified as high-strain were 1.78 times more likely to be in the second and third tertiles $\left(\mathrm{OR}_{1}\right)$ and 2.45 times to be in the third tertile $\left(\mathrm{OR}_{2}\right)$. Also, in the role emotional dimension, those with an inadequate effort-reward ratio were 2.12 times more likely to be in the third tertile $\left(\mathrm{OR}_{2}\right)$. With regard to job titles and the role emotional dimension, nurse technicians and nurse assistants were protected with scores in the lowest tertiles $\left(\mathrm{OR}_{1}=0.70\right.$ and $\left.\mathrm{OR}_{2}=0.48\right)$.

Table 1. Descriptive statistics of health dimensions in the study sample. Municipality of São Paulo, Southeastern Brazil, 2004-2005.

\begin{tabular}{|c|c|c|c|c|c|}
\hline Health dimension ${ }^{\mathbf{a}}$ & Mean & Median & SD & Minimum & Maximum \\
\hline Physical functioning & 81.3 & 85.0 & 18.8 & 10.0 & 100 \\
\hline Role physical & 74.9 & 100.0 & 32.3 & 0 & 100 \\
\hline Bodily pain & 60.1 & 61.0 & 20.1 & 10.0 & 100 \\
\hline General health & 71.0 & 72.0 & 18.1 & 5.0 & 100 \\
\hline Vitality & 52.7 & 50.0 & 19.6 & 0 & 100 \\
\hline Social functioning & 65.1 & 62.5 & 25.2 & 0 & 100 \\
\hline Role emotional & 69.0 & 100.0 & 34.5 & 0 & 100 \\
\hline Mental health & 63.9 & 64.0 & 18.5 & 8.0 & 100 \\
\hline
\end{tabular}

${ }^{\text {a }}$ Assessed using the SF-36. 
Table 2. Job title and groups of work demands and control in the study sample of nursing providers. Municipality of São Paulo, Southeastern Brazil, 2004-2005.

\begin{tabular}{lcccccccccc}
\hline \multirow{2}{*}{ Category } & \multicolumn{2}{c}{ Low-strain job } & \multicolumn{2}{c}{ Active job } & \multicolumn{2}{c}{ Passive job } & \multicolumn{2}{c}{ High-strain job } & \multicolumn{2}{c}{ Total } \\
& $\mathrm{n}$ & $\%$ & $\mathrm{n}$ & $\%$ & $\mathrm{n}$ & $\%$ & $\mathrm{n}$ & $\%$ & $\mathrm{n}$ & $\%$ \\
\hline Registered nurses & 54 & 34.6 & 68 & 43.6 & 16 & 10.3 & 18 & 11.5 & 156 & 100.0 \\
Nurse assistants/ technicians & 107 & 19.9 & 106 & 19.7 & 190 & 35.3 & 136 & 25.2 & 539 & 100.0 \\
\hline Total & 161 & 54.5 & 174 & 63.3 & 206 & 45.9 & 154 & 36.7 & 695 & 100.0 \\
\hline$\chi^{2}=74.779 ; \mathrm{p}<0.001$ & & & & & & & & & &
\end{tabular}

Table 3. Effort-reward ratio according to job title. Municipality of São Paulo, Southeastern Brazil, 2004-2005.

\begin{tabular}{|c|c|c|c|c|c|c|}
\hline \multirow{2}{*}{ Category } & \multicolumn{2}{|c|}{$\leq 1.00$} & \multicolumn{2}{|c|}{1.01 and more } & \multicolumn{2}{|c|}{ Total } \\
\hline & $\mathrm{n}$ & $\%$ & $\mathrm{n}$ & $\%$ & $\mathrm{n}$ & $\%$ \\
\hline Registered nurses & 137 & 87.8 & 19 & 12.2 & 156 & 100.0 \\
\hline Nurse assistants/technicians & 505 & 93.5 & 35 & 6.5 & 540 & 100.0 \\
\hline Total & 642 & 92.2 & 54 & 7.8 & 696 & 100.0 \\
\hline
\end{tabular}

$\chi_{c}^{2}=4.724 ; p=0.03$

\section{DISCUSSION}

The dimensions of HRQL with the lowest scores in the sample studied were vitality, bodily pain, and mental health. These results corroborate previous studies with the same population that showed fatigue and tiredness (vitality dimension) as factors associated with inadequate work ability, and musculoskeletal conditions. ${ }^{8}$ They are associated to severe and/or disabling pain conditions (bodily pain dimension), and high prevalence of minor mental disturbances, explaining low scores seen in the mental health dimension. ${ }^{8}$ The low scores in these dimensions have also been described in studies with other populations. ${ }^{15}$ It is likely that these dimensions are more sensitive to changes in health condition and small changes in health have a greater effect on these dimensions.

The lowest quality of life scores seen in mental health dimensions are a reflection of an organizational restructuring in the study hospital. Many providers were to be transferred to other departments or sites and/or were worried about the possibility of being laid off. ${ }^{8}$ Characteristics inherent to the nursing profession (e.g., heavy psychological burden) and poor macrosocial conditions in developing countries could explained the HRQL results found. ${ }^{16,19}$

The perception of working conditions as represented by the demand-control model for the professional categories studied is consistent with that reported by Araújo et $\mathrm{al}^{4}(2003)$ in their study on nursing providers. In fact, registered nurses perceived better working conditions than nurse technicians and nurse assistants and high control at work. These perceptions are consistent with their professional roles and job definitions. ${ }^{b}$ The range of activities for registered nurses gives them greater decision-making power and control over one's duties and the potential to exercise their skills and creativity. According to Leppanen \& Olkimuora ${ }^{14}$ (1987), in a combination of professions, challenges at work and the perception of the ability to perform tasks are reduced in lower hierarchical levels. The authors argue that nurse technicians and nurse assistants can perceive their work as monotonous and routine, despite the challenging and innovating nature of health professions.

As for the effort-reward model, most providers favorably assessed the relationship between effort and reward at work. When professional categories were compared, a greater proportion of registered nurses perceived an effort-reward imbalance and possibly felt not appreciated. Siegrist ${ }^{21}$ (1996) discussed the increase in explanatory power of his model with regard to working conditions and the impact on health by changing the focus of investigation from control to reward at work.

Underappreciation has been consistently reported in studies of working conditions and is one of the main reasons associated to the shortage of nursing providers in many developed countries ${ }^{7}$ and growing withdrawal from the nursing profession in Brazil. ${ }^{3}$

This study corroborates findings in other populations, ${ }^{18}$ showing that the two models (demand-control and effort-reward) are complementary. Registered nurses are active in terms of organization, which gives them greater control in their duties and enables them to make a broader assessment about working conditions. Such responsibilities, however, can translate into greater effort-demand imbalance. The job requirements of

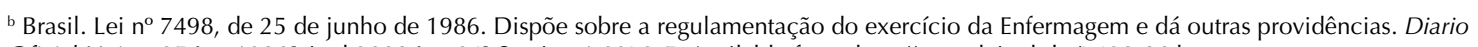
Oficial Uniao. 25 Jun 1986[cited 2008 Jun 04];Section 1:9273-5. Available from: http://www.lei.adv.br/7498-86.htm 
Table 4. Health dimensions and related odds ratio $\left(\mathrm{OR}_{1}\right.$ and $\left.\mathrm{OR}_{2}\right)$ in the multivariate analysis using partial proportional odds model. Municipality of São Paulo, Brazil, 2004-2005.

\begin{tabular}{|c|c|c|c|c|c|c|c|c|}
\hline \multirow[b]{2}{*}{ Demand-Control } & \multicolumn{6}{|c|}{ ERI ratio } & \multicolumn{2}{|c|}{ Job title } \\
\hline & $\begin{array}{l}\text { Low-strain } \\
\text { job }\end{array}$ & $\begin{array}{l}\text { Active } \\
\text { job }\end{array}$ & $\begin{array}{l}\text { Passive } \\
\text { job }\end{array}$ & $\begin{array}{c}\text { High- } \\
\text { strain job }\end{array}$ & $\leq 1.0$ & $>1.01$ & $\begin{array}{c}\text { Registered } \\
\text { nurse }\end{array}$ & $\begin{array}{l}\text { Nurse assistants/ } \\
\text { technicians }\end{array}$ \\
\hline \multicolumn{9}{|c|}{ Physical functioning } \\
\hline $\mathrm{OR}_{1}$ & 1 & 1.06 & 1.56 & 1.58 & 1 & 0.87 & 1 & 1.42 \\
\hline $\mathrm{OR}_{2}$ & 1 & 0.87 & 1.04 & 1.35 & 1 & 1.31 & 1 & 1.06 \\
\hline \multicolumn{9}{|l|}{ Role physical } \\
\hline $\mathrm{OR}_{1}$ & 1 & 1.12 & 1.49 & 1.07 & 1 & 1.07 & 1 & $0.54^{* *}$ \\
\hline $\mathrm{OR}_{2}$ & 1 & 0.99 & 1.54 & 1.55 & 1 & 1.12 & 1 & $0.61^{*}$ \\
\hline \multicolumn{9}{|l|}{ Bodily pain } \\
\hline $\mathrm{OR}_{1}$ & 1 & 1.08 & 1.44 & 1.43 & 1 & 1.27 & 1 & 1.39 \\
\hline $\mathrm{OR}_{2}$ & 1 & 0.93 & 1.05 & 1.69 & 1 & 1.68 & 1 & 0.78 \\
\hline \multicolumn{9}{|l|}{ General health } \\
\hline $\mathrm{OR}_{1}$ & 1 & 0.69 & 0.85 & 1.20 & 1 & $3.10^{*}$ & 1 & 1.30 \\
\hline $\mathrm{OR}_{2}$ & 1 & 0.93 & 1.26 & 1.04 & 1 & 1.22 & 1 & 0.72 \\
\hline \multicolumn{9}{|l|}{ Vitality } \\
\hline $\mathrm{OR}_{1}$ & 1 & $0.47^{*}$ & 1.14 & 0.78 & 1 & $3.02^{*}$ & 1 & 0.80 \\
\hline $\mathrm{OR}_{2}$ & 1 & 0.84 & 0.75 & 1.05 & 1 & $2.18^{*}$ & 1 & 0.81 \\
\hline \multicolumn{9}{|l|}{ Social functioning } \\
\hline $\mathrm{OR}_{1}$ & 1 & 0.98 & 1.51 & $1.73^{*}$ & 1 & $2.37^{*}$ & 1 & 0.90 \\
\hline $\mathrm{OR}_{2}$ & 1 & 0.59 & 0.84 & 1.65 & 1 & 2.48 & 1 & 0.75 \\
\hline \multicolumn{9}{|l|}{ Role emotional } \\
\hline $\mathrm{OR}_{1}$ & 1 & 1.31 & 1.48 & $1.78^{*}$ & 1 & 1.04 & 1 & $0.70^{*}$ \\
\hline $\mathrm{OR}_{2}$ & 1 & 1.61 & 1.75 & $2.45^{* *}$ & 1 & $2.12^{*}$ & 1 & $0.48^{* *}$ \\
\hline \multicolumn{9}{|l|}{ Mental health } \\
\hline $\mathrm{OR}_{1}$ & 1 & 1.11 & $2.09^{*}$ & 1.47 & 1 & 1.68 & 1 & 1.22 \\
\hline $\mathrm{OR}_{2}$ & 1 & 0.93 & 0.74 & 1.15 & 1 & $2.45^{* *}$ & 1 & 0.87 \\
\hline
\end{tabular}

$\mathrm{OR}_{1}$ : first tertile (reference) versus (second + third) tertiles; $\mathrm{OR}_{2}$ : (first + second) tertiles (reference) versus third tertile

* $\mathrm{p}<0.05 ;{ }^{* *} \mathrm{p} \leq 0.005$

Control variables: gender, age, head of household and marital status, number of jobs and work shifts, weekly working hours, professional category, social support at work, overcommitment, work-related injuries, cigarette smoking, alcohol use and physical exercise. Additional analyses are available in the online version of the article at: www.scielo.org.br/rsp

nursing technicians and assistants are less complex than those of registered nurses. Thus, technicians and assistants did not give special attention to psychosocial factors at work as registered nurses did.

A pattern of associations was seen in the final model (Table 4): the poorest working conditions perceived did not show significant OR for low scores when only physical health dimensions (physical functioning, role physical and bodily pain) were considered, except in nurse assistants (role physical). The opposite was seen for mental health dimensions or other associated dimensions (social functioning, role emotional, mental health, general health and vitality). Other authors have reported significant associations between psychosocial factors and perceptions about physical health or a specific physical condition, especially musculoskeletal pain. ${ }^{910,22}$ These findings can be explained by the fact that nursing technicians and assistants have predominantly physical demands in contrast to registered nurses that have predominantly mental demands. ${ }^{8,16}$ In the present study, mental health-related quality of life appears to be more relevant compared to that related to physical health when associated with the psychosocial factors studied. The association of these factors with the group of mental health dimensions reinforces and complements the finding of lower mean scores in these dimensions.

Among psychosocial factors, effort-reward imbalance is the most remarkable one. It has significant associations with all mental health dimensions, which suggests that this stressor is more important for this population than other aspects evaluated in the demand-control model, for example, high-strain job. In this sense, the organizational and social context, the relevance of different professional roles, the characteristics of coping with work demands, as well as fair treatment at work, were more explanatory for mental health-related 
quality of life in these providers. Stanfield et a ${ }^{23}$ (1998) made a similar remark when analyzing health predictors in civil servants and Gillen et $\mathrm{al}^{9}$ (2007) concluded that the demand-control model apparently did not fully capture the complexity of work with inpatients. Estryn-Béhar et $\mathrm{al}^{7}$ (2007) also showed that negative psychosocial environment and mental disorders were associated with nurses' early withdrawal.

This study has some limitations. It was conducted in a specific hospital setting, and the conditions of other hospitals in the same geographical area can be quite distinct. Also, current working conditions in the study hospital may now be different since major work reorganization was taking place at the time of data collection. ${ }^{6}$ And since this is a cross-sectional study, causal relationships cannot be inferred.

The results of this study point to the multidimensional aspects of quality of life. Thus, when variations associated with quality of life are observed, those factors which are most associated with the worst results, such as effort-reward conditions, must be prioritized for intervention.

In a macro-social context, health and safety at work should consider psychosocial factors for intervention and improvement of working conditions, since they influence the quality of life.

\section{ACKNOWLEDGMENTS}

To Prof. Paul Landsbergis of the Department of Environmental and Occupational Health Sciences, School of Public Health, State University of New York and Dr Lucia Rotenberg of Laboratório de Educação em Ambiente e Saúde, Instituto Oswaldo Cruz, Fiocruz, for their valuable suggestions in the preliminary phase of this study.

\section{REFERENCES}

1. Abreu MNS, Siqueira AL, Cardoso CS, Caiaffa WT. Ordinal logistic regression models: application in quality of life studies. Cad Saude Publica. 2008;24(Suppl 4):581-91. DOI: 10.1590/S0102311X2008001600010

2. Alves MCM, Chor D, Faerstein E, Lopes CS, Werneck GL. Versão resumida da "job stress scale": adaptação para o português. Rev Saude Publica. 2004;38(2):16471. DOI:10.1590/S0034-89102004000200003

3. Angerami ELS, Gomes DLS, Mendes IJM. Estudo da permanência dos enfermeiros no trabalho. Rev LatinoAm Enfermagem. 2000;8(5):52-7. DOI: 10.1590/ S0104-11692000000500008

4. Araújo TM, Aquino E, Menezes G, Santos CO, Aguiar L. Aspectos psicossociais do trabalho e distúrbios psíquicos entre trabalhadoras de enfermagem. Rev Saude Publica. 2003;37(4):424-33. DOI: 10.1590/ S0034-89102003000400006

5. Chor D, Werneck GL, Faerstein E, Mello Alves MC, Rotenberg L. The Brazilian version of the effort-reward imbalance questionnaire to assess job stress. Cad Saude Publica. 2008;24(1):219-24. DOI:10.1590/ S0102-311X2008000100022

6. Ciconelli RZ, Ferraz MR, Santos W, Meinão I, Quaresma MR. Tradução para a língua Portuguesa e validação do questionário genérico de avaliação de qualidade de vida SF-36 (Brasil SF-36). Rev Bras Reumatol. 1999;39(3):143-50.

7. Estryn-Béhar M, Van der Heijden BIJM, Oginska $\mathrm{H}$, Camerino D, Le Nézet O, Conway PM, et al. The impact of social work environment, teamwork characteristics, burnout, and personal factors upon intent to leave among European nurses. Med Care. 2007;45(10):939-50. DOI:10.1097/ MLR.0b013e31806728d8
8. Fischer FM, Borges FNS, Rotenberg L, Latorre MRDO, Soares NS, Landsbergis $\mathrm{P}$, et al. Work ability of healthcare shiftworkers: what matters? Chronobiol Int. 2006;23(6):1165-79.

9. Gillen M, Yen IH, Trupin L, Swig L, Rugulies R, Mullen $K$, et al. The association of socioeconomic status and psychosocial and physical workplace factors with musculoskeletal injury in hospital workers. Am J Ind Med. 2007;50(4):245-60. DOI:10.1002/ajim.20429

10. Heuvel GVD, Beek AJVD, Blatter BM, Hoogendoorn WE, Bongers PM. Psychosocial work characteristics in relation to neck and upper limb symptoms. Pain. 2005;114(1-2):47-53. DOI:10.1016/j. pain.2004.12.008

11. International Labour Organization. World Health Organization. Committee on Occupation Health. Recognition control of adverse psycho-social factors at work. Geneva; 1984.

12. Kuper H, Singh-Manoux A, Siegrist J, Marmot M. When reciprocity fails: effort-reward imbalance in relation to coronary heart disease and health functioning within the Whitehall II study. Occup Environ Med. 2002;59(11):777-84. DOI:10.1136/oem.59.11.777

13. Lall R, Campbell MJ, Walters SJ, Morgan K. A review of ordinal regression models applied on health-related quality of life assessments. Stat Methods Med Res. 2002;11(1):49-67. DOI:10.1191/0962280202sm271 ra

14. Leppanen A, Olkinuora MA. Psychological stress experienced by health care personnel. Scand J Work Environ Health. 1987;13(1):1-8.

15. Lerner DJ, Levine S, Malspeis S, Agostino RB. Job strain and health-related quality of life in national sample. Am J Public Health. 1994;84(10):1580-5. DOI:10.2105/AJPH.84.10.1580 
16. McVicar A. Workplace stress in nursing: a literature review. J Adv Nurs. 2003;44(6):633-42. DOI:10.1046/ j.0309-2402.2003.02853.x

17. Peter R, Siegrist J, Hallqvist J, Reterwall C, Theorell T, Shepp Study Group. Psychosocial work environment and myocardial infarction: improving risk estimation by combining two complementary job stress models in the Sheep Study. I Epidemiol Community Health. 2002;56(4):294-300. DOI:10.1136/jech.56.4.294

18. Rauhala A, Kivimaki M, Fagerstrom L, Elovainio $M$, Virtanen M, Vahtera J, et al. What degree of work overload is likely to cause increased sickness absenteeism among nurses? Evidence from the RAFAELA patient classification system. J Adv Nurs. 2007;57(3):286-95. DOI:10.1111/j.13652648.2006.04118.x

19. Rigotto RM. Saúde dos trabalhadores e meio ambiente em tempos de globalização e reestruturação produtiva. Rev Bras Saude Ocup. 1998;25(93-94):9-20.

20. Seidl EMF, Zannon CMLC. Qualidade de vida e saúde: aspectos conceituais e metodológicos. Cad Saude
Publica. 2004;20(2):580-8. DOI:10.1590/S0102$311 \times 2004000200027$

21. Siegrist J. Adverse health effects of high-effort/ low-reward conditions. J Occup Health Psychoc. 1996;1(1):27-41. DOI:10.1037/1076-8998.1.1.27

22. Simon M, Tackenberg P, Nienhaus A, Estryn-Behar M, Conway PM, Hasselhorn HM. Back or neckpain-related disability of nursing staff in hospital, nursing homes and home care in seven countriesresults from the European NEXT-STUDY. Int J Nurs Studies. 2007;45(1):24-34. DOI:10.1016/j. ijnurstu.2006.11.003

23. Stansfeld SM, Bosma H, Hemingway H, Marmot MG. Psychosocial work characteristics and social support as predictors of SF-36 health functioning: The Whitehall II Study. Psychosom Med. 1998;60(3):247-55.

24. Ware JE Jr, Sherbourne CD. The MOS 36-Item ShortForm Health Survey (SF-36) I. Conceptual Framework and Item Selection. Med Care. 1992;30(6):473-83. DOI:10.1097/00005650-199206000-00002

Fischer FM is supported by Conselho Nacional de Desenvolvimento Científico e Tecnológico (CNPq Productivity Grant CNPq IB Grant 301605/2009-2) and by Mount Sinai School of Medicine (Irving J. Selikoff International Scholar - Process $n^{\circ}$ D43TW000640).

The study was financed by Mount Sinai ITREOH Program supported by the Fogarty International Center (Grant nD43TW000640), Mount Sinai School of Medicine, New York, USA. The content is solely the responsibility of the authors and does not necessarily represent the official view of the Fogarty International Center or the National Institutes of Health. Silva AA was supported by São Paulo Research Foundation (FAPESP - Grant 06/58543-6; master's degree fellowship). Borges FNS was supported by the Brazilian Federal Agency for Support and Evaluation of Graduate Education (CAPES; doctoral fellowship).

Article based on the master's dissertation by Silva AA, presented to the Programa de Pós-Graduação em Saúde Pública, Faculdade de Saúde Pública, Universidade de São Paulo, in 2009.

The authors declare that there are no conflicts of interests. 


\section{WEB-ANNEX}

Table A1. Number $(\mathrm{N})$ and percentage (\%) of nursing providers crossing-over between demand-control and role emotional variables. Municipality of São Paulo, Southeastern Brazil, 2004-2005.

\begin{tabular}{lccccc}
\hline \multirow{2}{*}{ Role emotional } & Low-strain & Active & Passive & High strain & Total \\
\hline 1 & $97(61.0)$ & $90(52.3)$ & $112(54.6)$ & $69(45.1)$ & $368(53.4)$ \\
2 & $31(19.5)$ & $33(19.2)$ & $43(21.0)$ & $28(18.3)$ & $135(19.6)$ \\
3 & $31(19.5)$ & $49(28.5)$ & $50(24.4)$ & $56(36.6)$ & $186(27.0)$ \\
\hline Total & $159(100.0)$ & $172(100.0)$ & $205(100.0)$ & $153(100.0)$ & $696(100.0)$ \\
\hline
\end{tabular}

Table A2. Number $(\mathrm{N})$ and percentage (\%) of nursing professionals crossing-over between demand-control and role emotional variables. Municipality of São Paulo, Southeastern Brazil, 2004-2005.

\begin{tabular}{|c|c|c|}
\hline \multirow{2}{*}{$\begin{array}{l}\text { Role } \\
\text { emotional }\end{array}$} & \multicolumn{2}{|c|}{$\begin{array}{c}\text { Demand-control } \\
N(\%)\end{array}$} \\
\hline & Low-strain ${ }^{\mathbf{a}}$ & Active \\
\hline 1 & $97(61.0)$ & $90(52.3)$ \\
\hline 2 and 3 & $62(39.0)$ & $82(47.7)$ \\
\hline \multicolumn{3}{|c|}{$\mathrm{OR}_{1}$ Active $=82 \times 97 / 62 \times 90=1.42$} \\
\hline \multirow{2}{*}{$\begin{array}{l}\text { Role } \\
\text { emotional }\end{array}$} & \multicolumn{2}{|c|}{$\begin{array}{l}\text { Demand-control } \\
\qquad \mathrm{N}(\%)\end{array}$} \\
\hline & Low-strain ${ }^{\mathbf{a}}$ & Passive \\
\hline 1 & $97(61.0)$ & $112(54.6)$ \\
\hline 2 and 3 & $62(39.0)$ & $93(45.4)$ \\
\hline \multicolumn{3}{|c|}{$\mathrm{OR}_{1}$ Passive $=93 \times 97 / 62 \times 112=1.30$} \\
\hline \multirow{2}{*}{$\begin{array}{l}\text { Role } \\
\text { emotional }\end{array}$} & \multicolumn{2}{|c|}{$\begin{array}{c}\text { Demand-control } \\
N(\%)\end{array}$} \\
\hline & Low-strain ${ }^{\mathbf{a}}$ & High-strain \\
\hline 1 & $97(61.0)$ & $69(45.1)$ \\
\hline 2 and 3 & $62(39.0)$ & $84(54.9)$ \\
\hline \multicolumn{3}{|c|}{$\mathrm{OR}_{1}$ High-strain $=84 \times 97 / 62 \times 69=1.90$} \\
\hline
\end{tabular}

a Low-strain represents the reference category in each analysis.

Note: The totals in columns remain the same as in Table A1; the totals in the rows are the sum of each category (1) and (2 and 3 ) of Table A1.
Table A3. Number (N) and percentage (\%) of nursing professionals crossing-over between demand-control and role emotional variables. Municipality of São Paulo, Southeastern Brazil, 2004-2005.

\begin{tabular}{|c|c|c|}
\hline \multirow{2}{*}{$\begin{array}{l}\text { Role } \\
\text { emotional }\end{array}$} & \multicolumn{2}{|c|}{$\begin{array}{c}\text { Demand-control } \\
\mathrm{N}(\%)\end{array}$} \\
\hline & Low-strain ${ }^{\mathbf{a}}$ & Active \\
\hline 1 and 2 & $128(80.5)$ & $123(71.5)$ \\
\hline 3 & $31(19.5)$ & $49(28.5)$ \\
\hline \multicolumn{3}{|c|}{$\mathrm{OR}_{2}$ Active $=49 \times 128 / 31 \times 123=1.64$} \\
\hline \multirow{2}{*}{$\begin{array}{l}\text { Role } \\
\text { emotional }\end{array}$} & \multicolumn{2}{|c|}{$\begin{array}{l}\text { Demand-control } \\
\text { N (\%) }\end{array}$} \\
\hline & Low-strain ${ }^{\mathbf{a}}$ & Passive \\
\hline 1 and 2 & $128(80.5)$ & $155(75.6)$ \\
\hline 3 & $31(19.5)$ & $50(24.4)$ \\
\hline \multicolumn{3}{|c|}{$\mathrm{OR}_{2}$ Passive $=50 \times 128 / 31 \times 155=1.33$} \\
\hline \multirow{2}{*}{$\begin{array}{l}\text { Role } \\
\text { emotional }\end{array}$} & \multicolumn{2}{|c|}{$\begin{array}{l}\text { Demand-control } \\
\text { N (\%) }\end{array}$} \\
\hline & Low-strain ${ }^{\mathbf{a}}$ & High-strain \\
\hline 1 and 2 & $128(80.5)$ & $97(63.4)$ \\
\hline 3 & $31(19.5)$ & $56(36.6)$ \\
\hline
\end{tabular}

$\mathrm{OR}_{2}$ High-strain $=56 \times 128 / 31 \times 97=2.38$

${ }^{a}$ Low-strain represents the reference category in each analysis.

Note: The totals in columns remain the same as in Table A1; the totals in the rows are the sum of each category (1) and (2 and 3) of Table A1. 